\title{
ANALISIS WACANA KASUS PELECEHAN SEKSUAL TERHADAP PEREMPUAN PADA BERITA ONLINE DALAM PERSPEKTIF ANALISIS SARA MILLS
}

\author{
Yosi Zamzuardi, Syahrul \\ Universitas Negeri Padang, Indonesia \\ E-mail : yosizamzuardi.11@gmail.com
}

\begin{abstract}
This study discusses the discourse of sexual violence that occurs among women in online media coverage. Good media can display balanced information. Various reports related to sexual harassment often experienced by women can be represented in a discourse differently. At present the exploitation of women is carried out through more intellectual and neatly packaged methods, one of which is through discourse revealed in the mass media. Women in the media are positioned visually prominent, but also marginalized in meaning. If this continues, it will reinforce the existence of gender differences between women and men which has implications for the potential for increasing gender oppression with women as victims. The problem discussed in this study is a critical discourse analysis using the theory of Sara Mills. The discussion of Sara Mills around discourse theory makes the discourse of feminism a vortex of study. In addition, it also addresses women's issues such as how women are displayed in text, images, photos and in the news. The focus of this study is to examine 1) how the text experiences bias in representing women in the text, 2) how the marginalization of women is formed in weakening women's position.
\end{abstract}

Keywords: discourse analysis; sexual violence; Sara Mills

\begin{abstract}
Abstrak: Penelitian ini membahas tentang wacana kekerasan seksual yang terjadi di kalangan perempuan dalam pemberitaan media online. Media yang baik dapat menampilkan informasi yang berimbang. Berbagai pemberitaan terkait pelecehan seksual sering dialami perempuan dapat direpresentasikan ke dalam sebuah wacana secara berbeda-beda. Saat ini eksploitasi terhadap perempuan dilakukan melalui cara-cara yang lebih intelektual dan dikemas secara apik, salah satunya melalui wacana yang diungkap dalam media massa. Perempuan dalam media diposisikan yang menonjol secara visual, tetapi juga terpinggirkan dalam makna. Hal tersebut jika terus dibiarkan, akan mempertegas adanya perbedaan gender antara perempuan dengan lakilaki yang berimplikasi pada potensi meningkatnya penindasan gender dengan perempuan sebagai korbannya. Permasalahan yang dibahas dalam penelitian ini adalah analisis wacana kritis menggunakan teori Sara Mills. Pembahasan Sara Mills seputar teori wacana menjadikan wacana feminisme sebagai pusaran kajiannya. Selain itu juga membahas isu-isu perempuan seperti bagaimana perempuan ditampilkan dalam teks, gambar, foto serta dalam berita. Fokus penelitian ini yaitu mengkaji 1) bagaimana teks mengalami bias dalam merepresantasikan perempuan dalam teks, 2) bagaimana marginalisasi perempuan terbentuk dalam pelemahan posisi perempuan.
\end{abstract}

Kata Kunci : analisis wacana; kekerasan seksual; Sara Mills

Permalink/DOI: http://doi.org/10.15408/dialektika.v6i1.9750 


\section{Pendahuluan}

Wacana perempuan yang banyak dibahas adalah kodrat seorang wanita. Menurut Crystal dan Cook, dalam Nunan wacana merupakan unit bahasa lebih besar daripada kalimat, sering berupa satuan yang runtut/koheren dan memiliki tujuan dan konteks tertentu, seperti ceramah agama, argumen, lelucon atau cerita. ${ }^{1}$ Wacana perempuan sering diangkat ke media massa adalah perempuan merupakan makhluk yang lemah.

Pelecehan seksual terhadap perempuan sering terjadi dimana-mana. Berdasarkan data catatan tahunan komnas perempuan ditemukan 348.446 kasus kekerasan yang terjadi pada kaum perempuan. Jika dipersentasekan kekerasan fisik terletak pada tingkat pertama yaitu $41 \%$, dan kekerasan seksual berada pada tingkat kedua yakni $31 \%$, dan pada tingkat terakhir kekerasan ekonomi sebesar $13 \%{ }^{2}$ Walaupun kekerasan seksual terletak pada tingkat kedua, namun faktanya dampak yang ditimbulkan oleh kekerasan tersebut sangat merugikan korban. Hal ini disebabkan karena setelah hal tersebut dapat diobati secara medis, namun nyatanya masih meninggalkan bekas traumatis yang mendalam bagi korbannya.

Menurut Kompas.co (2018) kategori bentuk pelecahan inipun beragam, seperti pelecehan gender, perilaku menggoda, penyuapan seksual, pemaksaan seksual, dan pelanggaran seksual. Sementara itu, media komunikasi memegang peranan penting dalam mengisi dan mempengaruhi pembaca. Media yang baik dapat memuat berita yang berimbang dan faktual tanpa menyinggung pihak manapun. Namun pada kenyataannya media masa tak luput menampilkan representasi yang berbeda. Bahkan sering menggiring pemikiran pembaca kepada topik yang disajikan. Pernyataan tersebut dibuktikan dengan pendapat Foucoult (dalam Eriyanto, 2012:73), pandangan kita tentang suatu objek dibentuk dalam batas-batas yang telah ditentukan oleh struktur diskursif: wacana dicirikan oleh batasan bidang dari objek, definisi dari perspektif yang paling dipercaya dan dipandang benar.

Fenomena tersebut ditampilkan pula dalam pemberitaan media massa. Budi Setiawan, Yulianto (2011) menyebutkan realita kekerasan (violence), dan pelecehan ini sesungguhnya kontra produktif/ bertentangan dengan Sila Kedua

\footnotetext{
${ }^{1}$ Nunan, David. 1989. Designing Tasks For the Communicative Classroom. New York. Cambridge University Press.

${ }^{2}$ Catahu, 2018 merupakan lembar fakta dan point kunci catatan tahunan yang dikumpulkan selama 1 tahun oleh Komnas Perempuan.
} 
Pancasila yaitu 'Kemanusiaan Yang Adil dan Beradab', di mana deskripsi dari konsep sila tersebut lebih mengedepankan pada pengakuan publik untuk memperlakukan manusia sesuai dengan harkat dan martabatnya sebagai makhluk Tuhan Yang Maha Esa; pengakuan atas persamaan derajat, persamaan hak dan kewajiban asasi setiap manusia, tanpa membedakan-bedakan agama, kepercayaan, jenis kelamin/gender, warna kulit, keturunan, suku, dan kedudukan sosial; serta konsep sila ini menitikberatkan pada pengembangan sikap saling mencintai sesama manusia.

Berbagai pemberitaan terkait dengan pelecehan seksual dialami perempuan sebagai objek dalam pemberitaannya. Istilah representasi merujuk pada bagaimana kelompok, seseorang, gagasan atau pendapat tertentu ditampilkan dalam sebuah wacana. Berita menurut Nasution dalam Aliefadalah laporan tentang peristiwa-peristiwa atau kejadian yang terjadi yang ingin diketahui oleh umum, dengan sifatnya yang aktual, terjadi di lingkungan pembaca, mengenai tokoh terkemuka, akibat kejadian tersebut berpengaruh terhadap pembaca. ${ }^{3}$ Artinya pemberitaan dapat menimbulkan persepsi yang berbeda. Sejalan dengan pendapat tersebut, Eriyanto menyatakan bahwa persepsi kita tentang suatu objek dibentuk dengan dibatasi oleh pandangan yang mendefinisikan sesuatu bahwa yang ini benar dan yang lain tidak.

Saat ini eksploitasi terhadap perempuan dilakukan melalui cara-cara yang lebih intelektual dan dikemas secara apik, salah satunya melalui wacana yang diungkap dalam media massa. Secara tidak sadar, perempuanpun berada dalam pandangan sebagaimana yang dikontruksi oleh media. Peran media massa yang semestinya menjadi sarana bagi pencerdasan publik dan mendukung emansipasi perempuan menjadi terabaikan. Perempuan dalam media diposisikan dalam posisi yang menonjol secara visual, tetapi terpinggirkan dalam makna. Hal tersebut jika terus dibiarkan, akan mempertegas adanya perbedaan jender antara perempuan dengan laki-laki yang berimplikasi pada potensi meningkatnya penindasan jender dengan perempuan sebagai korbannya. Eksistensi wanita tidak terwakili pula secara proporsional di media massa, entah dalam industri media hiburan atau dalam industry media berita. ${ }^{5}$

\footnotetext{
${ }^{3}$ Alief.2008.”Konsep Dasar Berita”. Http://aliefnews.wordpres.com/2008/01/11/konsepdasar-berita/

${ }^{4}$ Eriyanto, 2009. Analisis Wacana : Pengantar Analisis Wacana. Yogyakarta : LKiS Yogyakarta.2009

${ }^{5}$ Sunarto. (2009). Televisi, Kekerasan \& Perempuan (Cetakan Pertama). Jakarta: Penerbit Buku Kompas.
} 
Gender merupakan sistem klasifikasi yang didasarkan pada jenis kelamin laki-laki dan perempuan sebagai bentuk biologis. Gender bukan hanya mengacu pada jenis kelamin biologis tetapi juga kondisi psikologis, sosial, budaya, serta ciri-ciri khusus lainnya yang diasosiasikan dengan kategori biologis perempuan dan laki-laki tersebut (Pam 1993, 11-36). Kemudian tercipta konsep maskulinitas dan feminitas yang dijadikan cara untuk mengaktualisasikan peran dari konsep jender tersebut sehingga menimbulkan pemahaman tentang perbedaan gender. Hal inilah yang akhirnya membuat kedudukan perempuan dan pengalaman mereka pada kebanyakan situasi berbeda dengan pengalaman dan kedudukan laki-laki yang juga mengalami situasi tersebut. Salah satu hal yang membuat timbulnya pemahaman mengenai perbedaan jender ini adalah adanya budaya patriarki yang mendominasi dan menunjukkan identitas laki-laki karena mereka dianggap kuat dalam segala hal, yang akhirnya mengonstruksi gambaran tentang perempuan dalam posisinya di masyarakat.

Salah satu penyebab terjadinya kekerasan dan lemahnya perlindungan hukum bagi wanita korban di Indonesia, kemungkinan dikarenakan eksistensi dari adanya sistem budaya patriarkal di masyarakat, di mana sistem pranata sosial ini mendasarkan pada relasi yang timpang menurut kategori kuat-lemah, pihak yang kuat menguasai dan menindas pihak yang lemah ataupun sistem budaya sosial yang memarjinalkan posisi wanita secara tetap di masyarakat, di mana seolah-olah melegitimasi berbagai macam ketidakadilan, perampasan dan penindasan yang dilakukan pelaku atas hak asasi wanita korban Murniati. ${ }^{6}$

Terkait hal tersebut dapat dikategorikan ke dalam golongan permasalahan feminisme. Wacana gerakan feminisme telah mengambil tempatnya tersendiri dalam masyarakat utamanya dalam lingkungan akademik. Kondisi ini turut mengantarkan gejolak gerakan feminisme sebagai suatu pendekatan teoritis juga tidak lagi dianggap sebagai hal tak membumi atau asing. Seorang feminis Indonesia pernah berkomentar bahwa esensi gerakan feminisme adalah perjuangan agar perempuan dan laki-laki tidak didiskriminasi di semua bidang kehidupan.

Pemaparan di atas menunjukkan bahwa pemberitaan di media massa tidak hanya sebatas menyampaikan wacana. Dalam konteks ini wacana melihat bahasa selalu terlibat dalam hubungan kekuasaan, terutama dalam pembentukan

${ }^{6}$ Setiawan, Yulianto Budi. 2011. Analisis Wacana Kritis Pemberitaan Kekerasan Berbasis Gender Di Surat Kabar Harian Suara Merdeka. Vol : 2, No. 11. Jurnal : Komunikasi Makna. Fakultas Komuniksi.

${ }^{7}$ Sadli, Saparinah. 2010. Berbeda tetapi Setara. Kompas Media Nusantara. Jakarta. 
subjek, dan berbagai tindakan representasi yang terdapat dalam masyarakat. ${ }^{8}$ Dalam memaparkan tidak semua peristiwa pantas diberitakan. Peristiwa hanya pantas diberitakan apabila mengandung nilai informatif bagi pembaca dan sesuai dengan tujuan media massa. ${ }^{9}$

Penelitian yang relevan dengan pelecahan terhadap perempuan tersebut sudah banyak dilakukan. Diantaranya adalah Ahmad, Hartanto dengan judul penelitian Analisis Wacana Pemberitaan Kekerasan pada Perempuan di halaman Patroli HU Solopos menyimpulkan bahwa pemberitaan kekerasan fisik pada kekerasan perempuan murni tindak criminal, dan kekerasaan ekonomi yang dialamai perempuan di HU Solopos menempatkan pihak kepolisian sebagai pencerita utama. ${ }^{10}$ Sementara Wulandari, Yuni dengan judul penelitian Representasi Korban Kekerasan Dalam Rumah Tangga Pada Rubrik "Nah Ini Dia" Di Surat Kabar Pos Kota (Analisis Wacana Sara Mills) menyimpulkan kemunculan korban KDRT dilakukan melalui empat tahap yaitu konstruksi karakter lelaki dan perempuan dalam teks pemberitaan (character), penggambaran bagian tubuh perempuan (fragmentation), sudut pandang gender (focalization) dan bagaimana ideologi dominan yang ada tumbuh dalam perbedaan gender. ${ }^{11}$ Selain itu juga mengalami Viktimisasi korban KDRT dalam judul pemberitaan "Nah Ini Dia" juga dimunculkan dengan pemilihan bahasa yang ringan dan penuh canda. Penggunaan bahasa maupun ungkapan yang penuh canda, hal ini membuat seolah-olah kasus KDRT yang menyakitkan korban menjadi sebuah hiburan tersendiri bagi khalayak pembacanya. Hal ini juga mengurangi keseriusan dari pemberitaan KDRT itu sendiri.

Penelitian kekerasan terhadap perempuan selanjutnya oleh Eko Prasetyo, Denny dengan judul Representasi Korban Kekerasan Dalam Rumah Tangga Pada Rubrik "Nah Ini Dia" Di Surat Kabar Pos Kota (Analisis Wacana Sara Mills) menyimpulkan bahwa dalam lead yang disajikan dalam teks berita

\footnotetext{
${ }^{8}$ Eriyanto, 2009. Analisis Wacana : Pengantar Analisis Wacana. Yogyakarta : LKiS Yogyakarta.2009. h. 4-6

${ }^{9}$ Siregar, Ashadi. 1998. Bagaimana Meliput dan Menulis Berita Untuk Media Massa. Yogyakarta : Penyunting Rondang Pasaribu, Kanisius. h. 21

${ }^{10}$ Hartanto, Ahmad. 2009. Skripsi : Analisis Wacana Pemberitaan Kekerasan Pada Perempuan Di Halaman Patroli HU Solopos. Komunikasi dan Penyiaran Islam Fakultas Dakwah : UIN Sunan Kalijaga.

${ }^{11}$ Wulandari, Yunni. 2014. Representasi Korban Kekerasan Dalam Rumah Tangga Pada Rubrik “Nah Ini Dia” Di Surat Kabar Pos Kota Analisis Wacana Sara Mills. Vol : 10, No. 02. Jurnal : Interaksi Online
} 
tersebut mnyatakan "Jumlah kasus kejahatan semakin meningkat di Indonesia." Minuman keras (Miras) dinilai sebagai penyebab bertambahnya kasus kriminal belakangan ini. Kasus pemerkosaan dan pembunuhan Yuyun, siswi SMP di Bengkulu dilakukan oleh 14 orang yang dipengaruhi miras”. Tidak hanya dibunuh Yuyun juga diperkosa secara bergantian oleh 14 orang pemuda akibat pengaruh minuman keras dan dianiaya hingga tewas.

Sehubungan dengat topik dan permasalahan tersebut, penulis tertarik memilih sebuah wacana dari berbagai sumber media berita yang ditulis oleh Tempo.co, dan sindonews.com untuk diteliti menggunakan teori Sara Mills. Penulis tertarik untuk menyorot isi berita tersebut karena dapat memiliki pengaruh dan representasi yang berbeda tentang perempuan di kalangan masyarakat pembaca harian. Sehingga analisis dengan pendekatan feminisme Sara Mills menjadil hal menarik untuk dilakukan.

Berdasarkan permasalahan tersebut, maka rumusan masalah penelitian adalah: (1) mendeskripsikan bagaimana teks mengalami bias dalam merepresantasikan perempuan dalam teks, (2) mendeskripsikan bagaimana marginalisasi perempuan terbentuk dalam pelemahan posisi perempuan.

\section{Metode}

Penelitian ini menggunakan rancangan penelitian deskriptif kualitatif dengan menggunakan metode dokumentasi dengan teknik baca-catat. Data yang diperlukan dalam penelitian ini adalah berita kekerasan seksual yang dialami oleh perempuan. Untuk mendapatkan dokumen tersebut, peneliti mengumpulkan berita yang dimuat dalam surat kabar sindonews.com dan tempo.co mulai dari tanggal 23 Januari 2018 - 17 Maret 2018 dengan jumlah sebanyak lima buah berita. Data tersebut akan dipaparkan secara kualitatif, yaitu dengan cara menggunakan uraian narasi disertai dengan pemaparan data.

Penelitian ini mengangkat pemberitaan mengenai perempuan korban kekerasan dalam rumah tangga yang seringkali terpinggirkan dalam pemberitaan. Berdasarkan dari konsep dari analisis ini, perempuan tersebut ditampilkan sebagai objek, bukan suara mereka yang ditampilkan. Gambaran tentang mereka seringkali ditampilkan oleh pihak lain, lengkap dengan segala bias dan prasangkanya.

${ }^{12}$ Eko Prasetyo, Denny. Analisis Berita Yuyun Dan Para Korban Kejahatan Akibat Minuman Keras Di Republika Online Edisi 7 Mei 2016. . Vol.4 No. 3. 2016. E-jurnal : Ilmu Komunikasi. 
Yosi Zamzuardi, Syahrul

\section{Kerangka Analisis}

Tabel 1. Kerangka Analisis Sara Mills

\begin{tabular}{ll}
\hline Tingkat & \multicolumn{1}{c}{ Yang Ingin Dilihat } \\
\hline Posisi & Bagaimana peristiwa dilihat dari kacamata siapa peristiwa itu dilihat. Siapa \\
Subjek & yang \\
Objek & diposisikan sebagai pencerita (subjek) dan siapa yang menjadi objek yang diceritakan. \\
& Apakah masing-masing aktor dan sosial mempunyai kesempatan untuk \\
& menampilkan dirinya sendiri, gagasannya atau kehadirannya. \\
Posisi & Bagaimana posisi pembaca ditampilkan dalam teks. Bagaimana pembaca \\
Penulis- & $\begin{array}{l}\text { memosisikan } \\
\text { Pembac }\end{array}$ \\
dirinya dalam teks yang ditampilkan kepada kelompok manakah pembaca
\end{tabular}

Analisis yang dilakukan dalam penelitian ini didasarkan pada kerangka analisis yang dijabarkan dalam tabel di atas (Eriyanto 2009, 211). Hal ini dilakukan untuk mendapatkan jawaban dari perumusan masalah yang telah disebutkan dalam bab 1. Perhatian utama dalam perpektif feminis adalah mencoba menunjukkan bagaimana teks bias dalam menggambarkan perempuan yang mana perempuan sering ditampilkan oleh teks sebagai pihak yang salah, lebih rendah dibandingkan dengan laki-laki. Penggambaran yang negatif serta ketidakadilan inilah yang menjadi perhatian utama Mills.

\section{Teknik Pengumpulan Data}

Teknik pengumpulan data yang dilakukan dalam penelitian ini diawali dengan mengumpulkan berita sebanyak 5 macam dari sumber yang berbeda. Sumber yang pertama dari Sindonews.com, dan yang kedua dari Tempo.co. Peneliti mengambil sampel rubrik yang dipublikasikan selama bulan Januari Maret 2018. Alasan pemilihan rentang waktu tersebut karena berdasarkan rubrik data yang ditemukan.

Setelah mengumpulkan data, peneliti menyeleksi kembali semua rubrik tersebut, dan secara purposive hanya memilih rubrik dengan tema yang benarbenar merepresentasikan pelecehan seksual terhadap perempuan. Selanjutnya, peneliti melakukan studi pustaka, yakni berupa kegiatan pengumpulan bahanbahan acuan yang relevan dengan penelitian ini melalui teks-teks tertulis seperti buku, e-book, artikel-artikel dalam majalah, surat kabar, buletin, jurnal, makalah, dan lain-lain. Peneliti kemudian melakukan analisa terhadap isi berita. Hal ini dilakukan untuk mengetahui karakteristik ideologi tersembunyi dalam bahasa, yang dikemas menjadi sebuah cerita. 


\section{Data}

Dalam penelitian ini, peneliti menggunakan data yang diperoleh lima rubrik yang terkait dengan pemberitaan mengenai pelecehan seksual terhadap perempuan dengan judul yang ditemukan sebagai berikut :

\begin{tabular}{|c|c|c|c|}
\hline No & Judul & Sumber & Tanggal Terbit \\
\hline 1 & $\begin{array}{l}\text { Perawat Yang Lecehkan Pasien } \\
\text { Laporkan Ke Polisi }\end{array}$ & Sindonews.com & $\begin{array}{l}\text { Kamis, 25 Januari } \\
2018\end{array}$ \\
\hline 2 & $\begin{array}{l}\text { Tersangka Kekerasan Seksual Jatinegara } \\
\text { Mengaku Tergoda Daster }\end{array}$ & Tempo.co & $\begin{array}{l}\text { Rabu, } 14 \\
\text { Februari2018 }\end{array}$ \\
\hline 3 & $\begin{array}{l}\text { Tergiur Tubuh Bongsor, Kuli Bangunan } \\
\text { Gagahi Anak Kandung }\end{array}$ & Sindonews.com & $\begin{array}{l}\text { Kamis, } 15 \text { Februari } \\
2018\end{array}$ \\
\hline 4 & $\begin{array}{l}\text { Pelecehan Seksual Kolam Citos Santer Di } \\
\text { Twitter }\end{array}$ & Tempo.co & $\begin{array}{l}\text { Jumat, } 23 \text { Maret } \\
2018\end{array}$ \\
\hline 5 & $\begin{array}{l}\text { Model Dylan Sada Korban Pelecehan Seksual : } \\
\text { Dia Ada Di Darah Saya }\end{array}$ & Tempo.co & $\begin{array}{l}\text { Sabtu, } \quad 17 \\
2018\end{array}$ \\
\hline
\end{tabular}

\section{Landasan Teori}

Secara metodologis, teori wacana Sara Mills banyak mengadopsi pandangan Foucault. Mills mengadopsi teori wacana Foucault sebagai ground teori dalam analisis wacana kritis. Pendekatan Foucault ini yang dikenal dengan analisis wacana pendekatan Prancis (French Discourse Analysis). Sara Mills dikenal sebagai feminis menunjukkan analisisnya yang menggambarkan relasi kekuasaan dengan ideologi. Jika ditilik kembali pada pendekatan Foucault, ditemukan suatu pandangan yang menekankan pada aspek kekuasaan yang disalurkan melalui hubungan sosial, dengan memproduksi bentuk-bentuk kategorisasi perilaku seperti baik dan buruk sebagai bentuk pengendalian perilaku.

Sara Mills melihat sebuah wacana pada bagaimana aktor ditampilkan dalam teks. Dalam artian siapa yang menjadi subyek dari penceritaan dan siapa yang menjadi obyek penceritaan akan menentukan bagaimana struktur teks dan makna diperlakukan dalam teks secara keseluruhan (Darma: 2014). Terkait dengan posisi aktor dalam teks, maka yang perlu diperhatikan adalah bagaimana subyek-obyek menempatkan representasi sebagai bagian terpenting.Dengan demikian hal ini mengarah kepada bagaimana satu pihak, kelompok, orang, gagasan dan peristiwa direpresentasikan dengan teknik tertentu dalam wacana dan menghadirkan makna kepada publik.

Pembahasan Sara Mills seputar teori wacana feminisme sebagai pusaran kajiannya, Sara Mills membahas isu-isu perempuan seperti bagaimana perempuan ditampilkan dalam teks, gambar, foto serta dalam berita. Hal ini 
yang menjadi dasar sehingga pendekatan teori wacana Sara Mills dikenal pula dengan wacana perspektif feminis. ${ }^{13}$

Selain memusatkan perhatian pada aktor dalam teks, Sara Mills juga menyorot aspek pembaca dan penulis direpresentasikan. Keterkaitannya dengan wacana adalah bagaimana pembaca mengidentifikasi dan menempatkan dirinya dalam alur teks. Kondisi ini memengaruhi bagaimana teks akan dipahami dan menghasilkan suatu keadaan dimana ada pihak yang dianggap legitimit dan ilegitimit. ${ }^{14}$

Titik perhatian dari wacana yang berperspektif feminis adalah menunjukkan bagaimana teks bias dalam menampilkan perempuan. Perempuan cenderung ditampilkan dalam teks sebagai pihak yang salah dan marginal dibandingkan dengan laki-laki. Sara Mills ingin menunjukkan bagaimana perempuan digambarkan dan dimarginalisasikan dalam teks berita, dan bagaimana bentuk dan pola permarginalan tersebut dilakukan. Mills menambahkan bahwa teks merupakan suatu hasil negosisasi antara penulis dan pembaca, dengan demikian maka pembaca tidak dianggap semata-mata sebagai penerima teks atau informasi tetapi juga ikut melakukan transaksi sebagaimana terihat dalam teks.

\section{Analisis Wacana Kritis}

Salah satu cara yang dapat dilakukan untuk mengetahui maksud dari pemberitaan di media massa, dalam hal ini terkait dengan kekerasan terhadap perempuan dalam rumah tangga adalah melalui analisis wacana. Analisis yang akan diuraikan dalam penelitian ini adalah analisis wacana dalam pemahaman kritis (Critical Discourse Analysis) terutama untuk melihat bagaimana analisis wacana kritis ini digunakan untuk membedah konten media. Dalam pandangan kritis, analisis wacana tidak dipusatkan pada kebenaran atau ketidakbenaran struktur tata bahasa atau proses penafsiran. Analisis wacana dalam pandangan kritis menekankan pada konstelasi kekuatan yang terjadi pada proses produksi dan reproduksi makna. (Eriyanto 2009, 8)

${ }^{13}$ Feminisme memiliki asal kata femme yang berarti perempuan, dimana ini adalah sebuah gerakan atau aktivitas perempuan yang memperjuangkan keseimbangan gender antara perempuan dan laki-laki dalam mendapatkan haknya dalam masyarakat sosial. Tujuan dari gerakan feminisme ini adalah tercapainya kesetaraan dan kesamaan hak serta kewajiban yang diterapkan pada semua gender yaitu perempuan dan laki-laki.

${ }^{14}$ Darma, Yoce Aliah. 2014. Analisis Wacana Kritis. Refika Aditama. Bandung. 


\section{Pembahasan}

\section{Analisis Posisi Subjek- Objek}

Berita yang berjudul "Perawat yang Lecehkan Pasien Cantik Dilaporkan ke Polisi” yang terbit pada hari Kamis, 25 Januari 2018. Bila dilihat dari judulnya memiliki makna yang dalam. Hal ini bila dikaitkan dengan kata "perawat" berhubungan dengan profesi yang ia kerjakan. Namun kenyataannya bertolak belakang dengan perbuatan telah ia lakukan. Idealnya seorang perawat bertanggung jawab menjaga dan merawat pasien. ${ }^{15}$ Sementara permasalahan yang terjadi tidak menggambarkan hal demikian. Kata "lecehkan" menekankan makna perbuatan yang meremehkan baik fisik dan non fisik terhadap seorang yang berbau pornografi. Penulis ingin menyampaikan suatu tindakan asusila yang tidak semestinya ia lakukan. Penggunaan kata "pasien" memiliki arti seorang yang butuh bantuan dan memerlukan perawatan.

Sementara kata "cantik" memiliki arti wanita yang secara fisik menarik. Hal ini memiliki makna yang dalam bila dilihat dari kosakatanya. Apabila seorang pasien yang seharusnya membutuhkan bantuan karena suatu penyakit, namun ia masih menarik dan terlihat enak dipandang. Ada makna tersembunyi bahwa pasien tersebut dalam keadaan yang wajah dan rupanya menarik. Hal ini menyudut dan melemahkan "pasien" tersebut, karena memiliki rupa wajah yang cantik seakan-akan layak mendapatkan perlakuan yang tidak menyenangkan tersebut.

Selanjutnya, penempatkan penulis berita sebagai subjeknya dapat dilihat pada data 1:

Pelaku dijerat dengan Pasal 290 KUHP dengan ancaman hukman maksimal 7 tahun penjara. Bunyi pasal ini, mencabuli seseorang dalam keadaan tidak sadar. "Kami berterima kasih korban sudah melaporkan masalah ini pada kepolisian. Ini merupakan kerjasama yang baik. Setelah ini kami akan segera melakukan pemeriksaan saksi-saksi. Baik itu saksi korban maupun saksi-saksi yang lain, termasuk perawat yang diduga sebagai pelaku," terangnya.

Pengunaan kata "pelaku" menunjukan posisi penulis sebagai subjeknya. Pada kata "pelaku" mengindikasikan bahwa memang benar telah terjadi pelecehan terhadap pasien tersebut. Selain itu, penempatan pembaca sebagai subjeknya membuat kejadian pelecehan tersebut memang harus ditindaklanjuti.

\footnotetext{
${ }^{15}$ Hakim, Lukman. "Perawat yang Lecehkan Pasien Cantik Dilaporkan ke Polisi .” Sindonews.co, 2018. https:/ / daerah.sindonews.com/read/1276650/23/perawat-yang-lecehkanpasien-cantik-dilaporkan-ke-polisi-1516872195
} 
Hal ini membuka mata masyarakat agar masyarakat mengetahui bahwa pelaku pencabulan dikenakan pasal 290 KUHP yakni dengan ancaman hukuman maksimal 7 tahun penjara. Apabila ada perempuan yang mengalami hal serupa sehingga tidak segan-segan untuk melaporkan kejadian tersebut pada yang berwenang

Di sisi lain "pasien cantik" sebagai objek dalam berita tersebut telah terjadi pelemahan makna. Sesuai dengan "data 1" tersebut pada kalimat "kami akan segera melakukan pemeriksaan saksi-saksi”. Hal ini memiliki makna bahwa kejadian pelecehan tersebut diduga apakah benar atau tidak seperti itu. Seorang pasien yang menerima perawatan masih disangsikan kebenaran laporannya karena dibawah pemulihan medis.

Selanjutnya terjadi penulisan nama korban pelecehan menggunakan inisial "W" selaku korban mendapatkan tindakan yang tidak senonoh. Hal ini terlihat pada data 2:

Dari keterangan yang kami dapatkan, pelaku menjalankan aksinya di ruang pemulihan. Jadi setelah korban yang berinisial W ini menjalani operasi, si pelaku memindahkannya ke rumah pemulihan. Nah, di ruang pemulihan inilah pelaku melakukan perbuatannya," kata Rudi.

Pada data di atas menunjukan nama korban dengan sebutan inisial "W". Hal ini merupakan kejadian yang memalukan sehingga korban tidak mau namanya terungkap oleh masyarakat. Namun inisial yang digunakan menggunakan inisial asli dari korban. Tidak semestinya penulis menuliskan dengan inisial nama tersebut, karena dapat membuat perasaan trauma yang mendalam.

Kemudian peristiwa pelecehan terjadi di ruang pemulihan pasca operasi. Pelaku melaksanakan aksinya ketika korban dalam keadaan di bawah pengaruh bius. Ketika dalam keadaan tidak berdaya ini pelaku memanfaatkan waktu tersebut untuk melakukan perbuatan asusila. Hal ini menunjukan perbuatan yang tidak pantas dilakukan oleh seorang yang berprofesi sebagai perawat dengan memanfaatkan kelemahan pasien untuk mengambil keuntungan. Tidak semestinya perawat melakukan perbuatan asusila karena bertentangan dengan sumpah jabatan keprofesiannya.

Pembahasan berita ke dua dengan judul “ Tersangka Kekerasan Seksual Jatinegara Mengaku Tergoda Daster”. ${ }^{16}$ Subjek dalam pemberitaan tersebut

\footnotetext{
${ }^{16}$ Hilmi, Alfan. "Tersangka Kekerasan Seksual Jatinegara Mengaku Tergoda Daster.” Tempo. co, 2018. https://metro.tempo.co/read/1060512/tersangka-kekerasan-seksual-jatinegara-mengakutergoda-daster
} 
adalah penulis. Ia menggambarkan dengan kata "pelaku" yang tiba-tiba bernafsu melihat korban. Hal ini terlihat dalam data 3 :

Kepala Kepolisian Sektor Jatinegara Komisaris Supadi mengatakan RA bertindak bejat semata-mata karena dorongan nafsu spontan. Tersangka tibatiba bernafsu melihat korban, 18 tahun, yang mengenakan daster menerawang karena terpapar cahaya lampu jalan malam itu. "Nah, dari belakang, bocah ini (RA) nafsu. Ya, sudah diraba-raba," kata Supadi saat dihubungi, Selasa ,13 Februari 2018.

Subjek pencerita pada berita ini terletak pada pelaku. Berdasarkan judul tersebut telah terjadi pelemahan dan merugikan si korban. Bila dianalisis judulnya memiliki makna tersirat bahwa korban yang menggundang aksi bejat pelaku karena menggunakan daster. Hal ini dipertegas ketika menerangkan dibagian judul "karena daster tersangka tergoda". Penggunaan baju daster yang tipis dianggap membuat tersangka tergoda untuk melakukan aksi bejatnya.

Baju daster merupakan baju yang lumrah untuk digunakan perempuan pada umumnya. Daster menurut KBBI merupakan gaun yang disengaja dibuat longgar untuk dipakai. Namun pelaku sengaja menjadikan daster sebagai alasan untuk melancarkan aksinya. Ketika pelaku melihat korban dengan menggunakan daster yang menerawang dan terpapar cahaya lampu jalan malam, ia pun tergoda. Hal ini seolah-olah membenarkan aksinya karena kesalahan si korban yang menggunakan baju daster.

Dalam berita tersbut menggambarkan bahwa perempuan merupakan kaum yang lemah, dan gampang saja menjadi santapan orang yang buas diluar sana ketika sudah tergiur dan tergoda. Bukan menceritakan objek sebagai penderita, tetapi mengesampingkan objek dan menonjolkan pelaku sebagai subjek yang layak diceritakan. Hal inilah yang direpsesantasikan dalam berita kedua.

Pada berita kedua, objek terletak pada korban pelecehan. Objek yang sejatinya korban namun menjadi sasaran kebiadaban seorang laki-laki dapat dilihat pada data 4 berikut ini :

Tersangka tiba-tiba bernafsu melihat korban, 18 tahun, yang mengenakan daster menerawang karena terpapar cahaya lampu jalan malam itu. "Nah, dari belakang, bocah ini (RA) nafsu. Ya, sudah diraba-raba," kata Supadi saat dihubungi, Selasa ,13 Februari 2018.

Hal ini seolah merupakan kesalahan korban yang dengan sengaja mengenakan daster agar dilecehkan secara seksual oleh pelaku. Korban juga seolah-olah layak untuk dilecehkan karena berjalan sendirian. Hal inilah yang 
direpresentasi dalam sebuah media tersebut. Perempuan yang tidak bisa melawan menjadi sasaran bagi laki-laki jahil. Perempuan rendah dan laki-laki menjadi objek yang ditonjolkan.

Pada berita ketiga dengan judul “ Tergiur tubuh bongsor, Kuli Gagahi Anak Kandung"17 tyang terbit hari kamis, tanggal 15 Februari 2018 dari Sindonews.com merupakan representasi pencerita pada pelaku sebagai subjeknya. Hal ini tergambar dari judul, yang melemahkan dan mengesampingkan korban. Hal yang sama juga dapat dilihat pada data 5 berikut ini :

Setiap kali melihat tubuh bongsor anaknya (Melati), SA mengaku terangsang. Dari awalnya mencabuli berubah menyetubuhi. Persetubuhan itu, kata SA kepada petugas terjadi empat kali. "Dalam kasus ini pelaku dijerat pasal berlapis UU Perlindungan Anak dengan ancaman maksimal 15 tahun penjara," tegas Hery.

Berdasarkan kutipan data diatas subjek penceritaan terletak pada pelaku, dan berita tersrbut melemahkan dan mengesampingkan korbannya. Penulis menceritakan bahwa hal yang membuat tergiur adalah ketika melihat tubuh bongsor anakknya, dan membuat pelaku menjadi tersangsang. Salain meakukan pelecehan seksual, ia juga tega merenggut kehormatan darah dagingnya hanya kaena alasan terangsang. Sungguh berbeda dengan orangtua pada umumnya. Orang tua yang seharusnya mengayomi dan menjaga keluarga namun, tega menggambil kehormatan anaknya sendiri.

Posisi pelaku sebagai aktor dikedepankan dalam berita ini, dan keberpihak berada pada pelaku. Sementara posisi objek tidak tergambar pada berita ini. Hal ini melemahkan korban dan menyudutkan sisi perempuan. Perempuan yang disalahkan karena memiliki tubuh bongsor menyebabkan mengundang hasrat pelaku.

Pada berita ketiga, objek terletak pada korban yang dilecehkan oleh ayah kandungnya. Objek masih dirugikan pada pemberitaan media ini. Hal ini dapat dilihat pada data 6 berikut ini :

BLITAR - DA (43) warga Sukorejo, Kota Blitar memergoki SA (50) suaminya menyingkap rok Melati (nama samaran) buah hati mereka yang masih kelas 1

17 Arif, Solichan. "Tergiur Tubuh Bongsor, Kuli Bangunan Gagahi Anak Kandung." Sindonews.co, 2018. https://daerah.sindonews.com/read/1282266/23/tergiur-tubuh-bongsor-kulibangunan-gagahi-anak-kandung-1518638602 
SMP. Tidak hanya mencabuli. Di dalam kamar itu SA juga merenggut kehormatan darah dagingnya sendiri.

Pada berita tersebut objek masih dijadikan korban yang dirugikan. Selain melakukan pelecehan seksual, kehormatan korban juga tega direnggut oleh sang ayah. Objek juga dikerdilkan dalam wacana ini karena memiliki tubuh bongsor sehingga layak untuk disetubuhi. Selain mengalami hal tersebut, korban juga mendapatkan ancaman apabila melaporkan hal tersebut maka ia akan diusir dari rumah. Karena alasan inilah korban takut, dan tidak berani untuk melaporkan kejadian tersebut, sehingga kejadian tersebut berulang kali terjadi. Sungguh miris sekali dan menyedihkan sekali nasib korban sehingga tidak bisa berbuat apa-apa.

Pada berita keempat dengan judul "Pelecehan Seksual Kolam Citos Santer di Twitter"18 pada koran Tempo.co hari Jumat 23 Maret 2018 menceritakan subjek sebagai pembaca. Ia menggambarkan sesuai dengan pandangan pembaca. Hal ini dapat dilihat pada data 7 berikut ini :

Berdasarkan informasi yang diterima Badri, sebelum kejadian pelaku memuji otot tubuh korban di kamar ganti yang berjarak beberapa meter dari bibir kolam renang. Kamar ganti bersebelahan dengan ruang penukaran kunci, tempat Badri bertugas.

Objek dalam berita tersebut berada diposisi korban. Korban yang masih dibawah umur menjadi sasaran empuk bagi para pelaku, hal ini tergambar pada data 8:

Korbannya siswa setingkat sekolah menengah atas pada Rabu, 14 Maret 2018. "Tapi baru ketahuan pelakunya Kamis kemarin (22 Maret 2018). Badri menceritakan bahwa korban adalah peserta les renang setiap Rabu. Seorang pria yang diketahui berinisial RDMS menghampiri korban lalu meraba tubuh korban. "Gak sampai ke sini juga (menunjuk organ vital), baru pegang-pegang lengan dan dada korban."

Data tersebut menggambarkan bahwa korban masih di bawah umur, yang memang belum bisa menjaga diri dari tindakan pelecehan tersebut menjadi sasaran empuk bagi pelaku. Kejadian dirasakan korban saat korban mengikti kegiatan les renang. Ia mengikuti korban hingga keruang ganti.

\footnotetext{
${ }^{18}$ Pebrianto, Fajar. "Pelecehan Seksual Kolam Citos Santer di Twitter: Ini Kronologinya ." Tempo.co, 2018. https://metro.tempo.co/read/1072539/pelecehan-seksual-kolam-citos-santer-ditwitter-ini-kronologinya
} 
Selanjutnya pada berita kelima dengan judul " Model Dylan Sada Korban Pelecehan Seksual : Dia ada di Darah Saya" ${ }^{\prime 19}$ pada berita tempo.co hari Sabtu, 17 Maret 2018 menceritakan subjek sebagai pelaku yang keji. Hal ini tergambar pada data 9 :

Dylan Sada menceritakan efek psikologis dari pengalaman pahit tersebut. "Saya mengalami pelecehan seksual oleh ayah kandung saat masih muda. Sulit dipercaya saya masih mengingat kejadian itu dengan jelas," tulis Dylan Sada yang kini berusia 34 tahun.

Pada data tersebut menjelaskan bahwa subjek berada pada posisi pembaca. Dimana akibat ulah pelaku korban mengalami efek psikologis yang begitu panjang meski sudah bertahun-tahun lamanya.

Pada berita kelima objek wacana terdapat pada korban. Korban yang masih dibawah umur menjadi sasaran empuk bagi para pelaku, hal ini tergambar pada data 10:

Korbannya siswa setingkat sekolah menengah atas pada Rabu, 14 Maret 2018. "Tapi baru ketahuan pelakunya Kamis kemarin (22 Maret 2018). Badri menceritakan bahwa korban adalah peserta les renang setiap Rabu. Seorang pria yang diketahui berinisial RDMS menghampiri korban lalu meraba tubuh korban. "Gak sampai ke sini juga (menunjuk organ vital), baru pegang-pegang lengan dan dada korban."

Pada kutipan berita di atas menceritakan bagaimana kronologi persitiwa terjadi. Dimana pelaku yang awalnya mendekati korban dengan jalan memuji otot tubuh korban an melakukan aksinya.

Selanjutnya posisi objek terletak pada korban. Korban merasakan permasalahan psikologi yang tidak hilang dalam jangka waktu yang lama yang dapat dilihat pada data 11 berikut ini:

Tapi kenyataannya, dia tak bisa lari dari masa lalu yang suram. "Peristiwa itu sangat mempengaruhi saya. Saya akhirnya beralih ke alkohol dan narkoba. Apapun yang bisa membuat saya merasakan sesuatu," tulisnya.Sejak pelecehan seksual itu terjadi, Dylan Sada merasa jiwanya berantakan. Pelaku pelecehan yang tak lain adalah ayah kandungnya membuatnya bingung dalam memaknai tubuh. "Saya benci karena saya adalah darah dagingnya dan dia ada di dalam darah saya," tulisnya.

${ }^{19}$ Rini, Kustiani. "Model Dylan Sada Korban Pelecehan Seksual : Dia Ada di Darah Saya." Tempo.co, 2018. https://cantik.tempo.co/read/1070546/model-dylan-sada-korban-pelecehanseksual-dia-ada-di-darah-saya 
Banyak kerugian yang ia alami sejak kejadian pelecehan yang ia rasakan. Ia tidak bisa melanjutkan hubungan yang baik di lingkungan sosialnya walaupun sudah pindah ke luar negeri. Selain itu ia memiliki rasa trauma untuk membangun hubungan dengan laki-laki karena ia mengaku sulit untuk mempercayai laki-laki. Hingga sekarang ia tidak habis pikir kejadian itu, kenapa seorang ayah kandung bisa tega melakukan hal itu padahal di dalam darahnya mengalir darah ayahnya.

\section{Penutup}

Keseluruhan teks berita ini menggambarkan bagaimana posisi subjek dan objek penceritaan menetukan bagaimana teks hadir kepada khalayak pembaca. Teks berita itu sangat bias gender, karena peristiwa tersebut diceritakan dalam pandangan laki-laki; lengkap dengan prasangka dan pemilihannya. Wanita bukan hanya tidak ditampilkan, tetapi kehadirannya bahkan ditampilkan oleh laki-laki. Tidak mengherankan, dalam teks semacam ini wanita selalu menjadi objek, selalu dipandang dan direpresentasikan secara buruk. Sebaliknya, laki-laki dihadirkan dan ditampikan dalam citra baik karena mereka yang menceritakan dan memiliki kisah dunia.

Dari kalimat yang terdapat pada data ditemukan bentuk perspektif yang melemahkah posisi perempuan. Meskipun sudah terdapat bukti tindak kekerasan seksual yang dilakukan oleh pelaku, dan diperkuat oleh laporan dan testimoni korban, namun harus dibuktikan secara medis dan yang terpenting adalah membuktikan bahwa para tersangka tersebut tidak bersalah.

Dengan melihat pada keseluruhan bagunan wacana dalam berita ini, maka posisi penulis merupakan subyek (pencerita) pada berita ini sementara posisi pembaca tidak disertakan atau ekslusif, dimana tidak ditemukan hal-hal atau data yang mendukung keterlibatan pembaca dalam teks yang dihasilkan.

Berdasarkan uraian pada pembahasan di atas, maka penulis dapat menarik beberapa kesimpulan sebagai berikut:

1. Bahwa teks berita telah mengalami bias dalam merepresentasikan perempuan dalam teks berita berdasarkan 5 jenis berita dalam media.

2. Marginalisasi perempuan terwujud dalam bentuk pelemahan posisi perempuan misalnya, ketika perempuan bepergian sendirian, memiliki postur tubuh yang bongsor, wajah yang cantik, dan juga dalam kondisi yang sepi diperlakukan dengan hal yang tak pantas.

3. Perspektif dalam berita melemahkan posisi perempuan meskipun sudah terbukti bukti kekerasan dilakukan oleh pelaku. 
4. Tindak pelecehan seksual terhadap perempuan menjadi agenda gerakan feminis agar meningkatkan rasa aman terhadap perempuan itu sendiri dimana ia berada.

5. Di zaman globalisasi masih terdapat berita yang memarginalsisikan dan merugikan kaum perempuan. Representasi inilah yang muncul dalam wacana jika dianalisis menggunakan teori Sara Mills. Subjek sebagai aktor yang ditampilkan dan ditonjolkan, bukan objek sebagai korban. Sementara wacana yang baik dapat menceritakan teks dengan baik dan berimbang.

\section{Daftar Pustaka}

Alief, Z. 2006. Perubahan dan Pergeseran Bentuk Mainan Anak Masyarakat Sunda. Jurnal Rekacipta 2(2). Kelompok Keilmuan Desain \& Budaya Visual-ITB. Bandung.

Alief. 2008. "Konsep Dasar Berita". http://aliefnews.wordpres.com/2008/01/ 11/konsep-dasar-berita/

Arif, S. "Tergiur Tubuh Bongsor, Kuli Bangunan Gagahi Anak Kandung." Sindonews.co, 2018. https://daerah.sindonews.com/read/ 1282266/23/tergiur-tubuh-bongsor-kuli-bangunan-gagahi-anak-kandung1518638602.

Darma, Y. A. 2014. Analisis Wacana Kritis. Refika Aditama. Bandung.

Eriyanto, 2009. Analisis Wacana: Pengantar Analisis Wacana. Yogyakarta : LKiS Yogyakarta. 2009.

Eriyanto. 2012. Analisis Wacana (Pengantar Analisis Teks Media). Yogyakarta: LkiS.

Hakim, L. "Perawat yang Lecehkan Pasien Cantik Dilaporkan ke Polisi". Sindonews.co, 2018. https://daerah.sindonews.com/read/1276650/23/ perawat-yang-lecehkan-pasien-cantik-dilaporkan-ke-polisi-1516872195.

Hartanto, A. 2009. Analisis Wacana Pemberitaan Kekerasan Pada Perempuan Di Halaman Patroli HU Solopos. Skripsi. Komunikasi dan Penyiaran Islam Fakultas Dakwah : UIN Sunan Kalijaga.

Hilmi, A. "Tersangka Kekerasan Seksual Jatinegara Mengaku Tergoda Daster”. Tempo. co, 2018. https://metro.tempo.co/read/1060512/ tersangka-kekerasan-seksual-jatinegara-mengaku-tergoda-daster.

Nunan, D. 1989. Designing Tasks For the Communicative Classroom. New York. Cambridge University Press. 
Pebrianto, F. "Pelecehan Seksual Kolam Citos Santer di Twitter: Ini Kronologinya”. Tempo.co, 2018. https://metro.tempo.co/read/ 1072539/pelecehan-seksual-kolam-citos-santer-di-twitter-inikronologinya.

Prasetyo, D.E. Analisis Berita Yuyun dan Para Korban Kejahatan Akibat Minuman Keras Di Republika Online Edisi 7 Mei 2016. eJournal Ilmu Komunikasi, 4(3), 127-141.

Rini, K. "Model Dylan Sada Korban Pelecehan Seksual : Dia Ada di Darah Saya”. Tempo.co, 2018. https://cantik.tempo.co/read/1070546/ modeldylan-sada-korban-pelecehan-seksual-dia-ada-di-darah-saya.

Sadli, S. 2010. Berbeda tetapi Setara. Kompas Media Nusantara. Jakarta.

Setiawan, Y. B. 2011. Analisis Wacana Kritis Pemberitaan Kekerasan Berbasis Gender di Surat Kabar Harian Suara Merdeka. Jurnal: Ilmu Komunikasi Makna 2(1). 13-20.

Siregar, A. 1998. Bagaimana Meliput dan Menulis Berita Untuk Media Massa. Yogyakarta : Penyunting Rondang Pasaribu, Kanisius.

Sunarto. 2009. Televisi, Kekerasan \& Perempuan (Cetakan Pertama). Jakarta: Penerbit Buku Kompas.

Wulandari, Y. 2014. Representasi Korban Kekerasan Dalam Rumah Tangga Pada Rubrik "Nah Ini Dia" Di Surat Kabar Pos Kota (Analisis Wacana Sara Mills). Jurnal : Interaksi Online, 10(2). 